\title{
Clinicopathological Study of Orchidectomy Lesions
}

\author{
Authors \\ Reeta Dhar ${ }^{1}$, Deesha Bhemat ${ }^{2}$ \\ ${ }^{1}$ Head of Department, Department of Pathology, MGM Medical College, Kamothe, Navi Mumbai \\ ${ }^{2} 2^{\text {nd }}$ year Resident, Department of Pathology, MGM Medical College, Kamothe, Navi Mumbai \\ Corresponding Author \\ Dr Deesha Bhemat
}

2nd Year Resident, Pathology Dept, MGM Medical College, Kamothe, Navi Mumbai, Maharashtra, India, Email: deesharamjiyani@gmail.com,Mob-+919173659525

\begin{abstract}
Testicular tumors are relatively rare and constitute fourth most common cause of death from neoplastic conditions in young male population. They are of great interest and importance because of varied histological appearance and diverse views regarding histogenesis. A study was conducted involving 50 cases and each specimen was examined for gross and histopathological examinations. The result of study showed a relatively low frequency of testicular tumors compared to non-neoplastic lesions. Despite all the new techniques in imaging and tumor marker assay the diagnosis of testicular lesion is primarily dependent upon histopathogical examination.
\end{abstract}

Keywords: Testicular lesions, Neoplastic, Non-neoplastic.

\section{Introduction}

Testis is affected by both non-neoplastic and neoplastic conditions. Testicular tumors are relatively rare and constitute fourth most common cause of death from neoplastic conditions in young male population. ${ }^{[1]}$ They are of great interest and importance because of varied histological appearance and diverse views regarding histogenesis.

Clinical data, investigations, operative findings, gross features and histopathological examination of lesions may provide important and at times decisive diagnostic clues. Objective is to study incidence of both neoplastic and non-neoplastic lesions in orchidectomy specimens to determine incidence and age wise distribution.

\section{Materials \& Methods}

A study was conducted involving 50 cases from November 2012 to 2016 (5 year). Specimens of orchidectomy in history of prostate carcinoma are also included in the study. Clinical details and investigation was recorded. Each specimen was subjected to gross examination and histopathological features were noted on $\mathrm{H} \& \mathrm{E}$ stained slides of all specimens.

\section{Results}

Out of 50 orchidectomy specimens 11 were neoplastic and 39 were non-neoplastic lesions. Among non-neoplastic lesions 11 showed normal testicular tissue, 8 atrophic testis, 6 cases involved both testicular infarct and gangrenous testis, 4 


\section{JMSCR Vol||05||Issue||05||Page 21770-21773||May}

maturation arrest, 3 torsion testis, 2 chronic non specific epididymo-orchitis, 2 cryptorchidism, 2 hematocele, 1 granulomatous orchitis. Neoplastic lesions included 3 classical seminoma, 3 mixed germ cell tumor, 3 sertoli cell tumors, 1 embryonal carcinoma and 1 yolk sac tumor.

Most of testicular lesions were more common in age group of 20-30 yrs and unilateral involvement of right sided testis was more common than bilateral involvement of testis. All patients had a similar complaint of testicular swelling and pain along with fever and revealed a hypoechoeic mass which showed vascularity on affected side on USG.

\section{Figure 1}

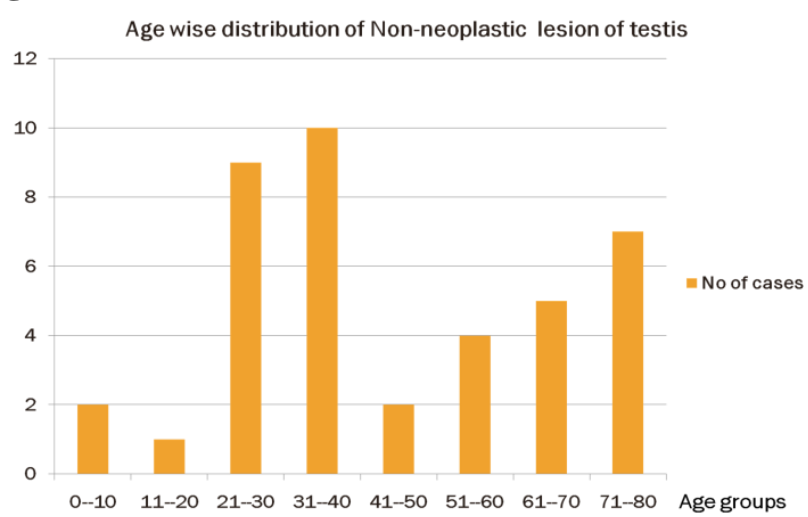

Figure 2

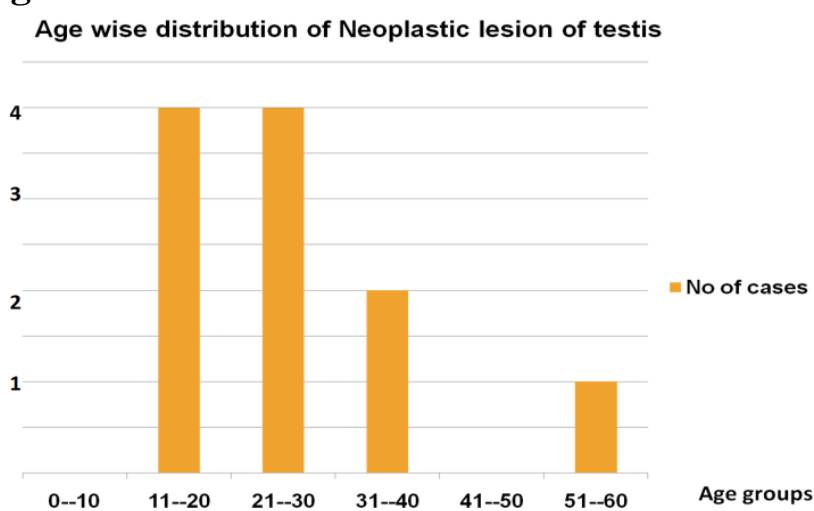

Figure 3

\section{Neoplastic lesion of testis}

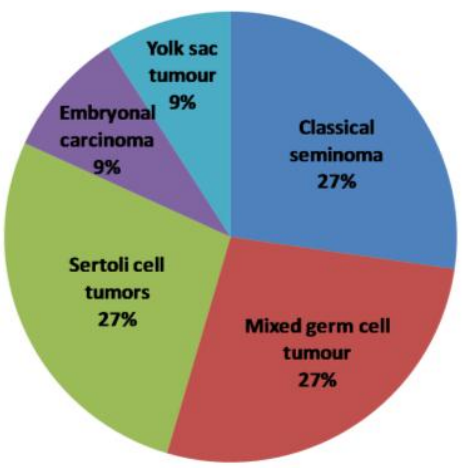

Figure 4

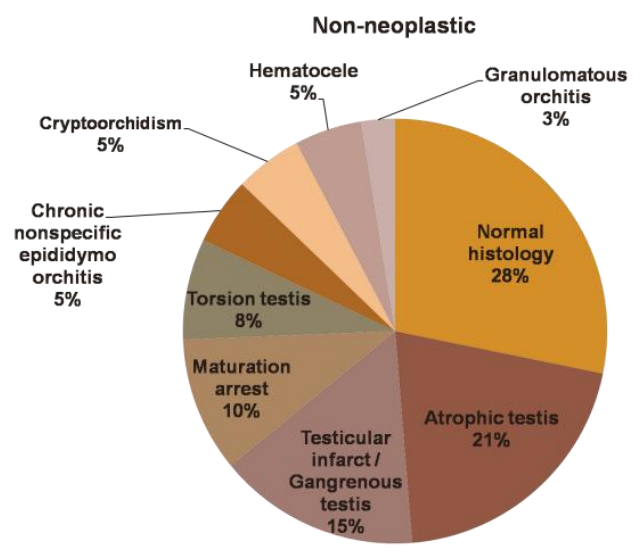

Figure 5

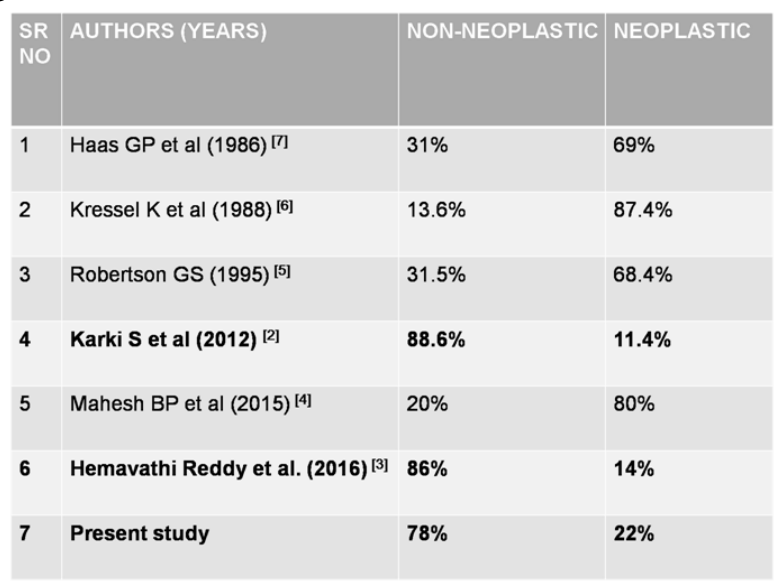

Table 1: Distribution of non neoplastic lesions

\begin{tabular}{|l|c|c|c|c|c|c|c|c|}
\hline Name & $11-20$ & $21-30$ & $31-40$ & $41-50$ & $51-60$ & $61-70$ & $>70$ & Total(n=39) \\
\hline $\begin{array}{l}\text { Normal testicular } \\
\text { tissue }\end{array}$ & 0 & 1 & 0 & 2 & 2 & 2 & 4 & $11(28 \%)$ \\
\hline Testicular atrophy & 1 & 3 & 4 & 0 & 0 & 0 & 0 & $08(21 \%)$ \\
\hline Maturation arrest & 0 & 1 & 1 & 0 & 0 & 1 & 1 & $04(10 \%)$ \\
\hline $\begin{array}{l}\text { Testicular } \\
\text { infarct }\end{array}$ & 0 & 2 & 0 & 0 & 0 & 1 & 0 & $03(7.5 \%)$ \\
\hline $\begin{array}{l}\text { Gangrenous } \\
\text { Testis }\end{array}$ & 0 & 1 & 1 & 0 & 0 & 0 & 1 & $03(7.5 \%)$ \\
\hline Torsion testis & 1 & 0 & 2 & 0 & 0 & 0 & 0 & $03(8 \%)$ \\
\hline $\begin{array}{l}\text { Undescended } \\
\text { testis }\end{array}$ & 1 & 0 & 1 & 0 & 0 & 0 & 0 & $02(5 \%)$ \\
\hline $\begin{array}{l}\text { Chronic } \\
\text { nonspecific } \\
\text { epididymo-orchitis }\end{array}$ & 0 & 0 & 0 & 0 & 1 & 1 & 0 & $02(5 \%)$ \\
\hline Hematocele & 0 & 1 & 0 & 0 & 1 & 0 & 0 & $02(5 \%)$ \\
\hline $\begin{array}{l}\text { Granulomatous } \\
\text { Orchitis }\end{array}$ & 0 & 0 & 1 & 0 & 0 & 0 & 0 & $01(3 \%)$ \\
\hline
\end{tabular}

Table 2: Distribution of neoplastic lesion

\begin{tabular}{|l|c|c|c|c|c|l|}
\hline Name & $\mathbf{1 1 - 2 0}$ & $\mathbf{2 1 - 3 0}$ & $\mathbf{3 1 - 4 0}$ & $\mathbf{4 1 - 5 0}$ & $\mathbf{5 1 - 6 0}$ & $\begin{array}{l}\text { Total } \\
(\mathbf{n}=\mathbf{1 1})\end{array}$ \\
\hline Classical seminoma & 2 & 0 & 1 & 0 & 0 & $\mathbf{3 ( 2 7 \% )}$ \\
\hline $\begin{array}{l}\text { Mixed germ cell } \\
\text { tumour }\end{array}$ & 0 & 3 & 0 & 0 & 0 & $\mathbf{3 ( 2 7 \% )}$ \\
\hline Sertoli cell tumour & 1 & 0 & 1 & 0 & 1 & $\mathbf{3 ( 2 7 \% )}$ \\
\hline Embryonal carcinoma & 0 & 1 & 0 & 0 & 0 & $\mathbf{1 ( 9 \% )}$ \\
\hline Yolk sac tumour & 1 & 0 & 0 & 0 & 0 & $\mathbf{1 ( 9 \% )}$ \\
\hline
\end{tabular}

\section{Discussion}

Various authors studied the incidence of benign and malignant lesions, which were compared with the present study. In present study most common 
lesions has non-neoplastic etiology. Neoplastic etiology constituted $22 \%$ and non-neoplastic etiology constituted $78 \%$. We correlated our study with other 6 studies which are Hemavathi Reddy et al (2016), Mahesh BP et al (2015), Karki S et al (2012), Robertson GS (1995), Kressel K et al (1988), and Hass GP et al (1986) ${ }^{[2,3,4,5,6,7]}$. Our study is correlating to studies of Karki $S$ et al (2012) \& Hemavathi Reddy et al $(2016)^{[2,3]}$.

Non neoplastic lesions are commonest in age group of 31-40 yrs (10 cases) followed by 21-30 yrs (9 cases). Normal testicular tissue was found to be commonest in non-neoplastic etiology which comprised $28 \%$ out of all. Most of them have history of prostate cancer. Atrophic testis (21\%) was the second most common lesion which was closely correlating with the study done by Hemavathi Reddy et al $(19.8 \%)^{[3]}$. Relative frequency of testicular torsions, testicular infarct, gangrenous testis comprised together $18 \%$ in present study and which were $22 \%, 10.1 \%$, and $13.1 \%$ in studies done by Hemavathi Reddy et al, Srinivasn A et al, and Rizvi SA et al respectively ${ }^{[3][8][9]}$.

Cryptorchidism comprised 5\%, however none of them showed malignancy, while it was about $8.24 \%$ in the study by Mahesh BP, et al (2015) ${ }^{[4]}$. We had also lesions like maturation arrest and hematocele which comprised $10 \%$ \& $5 \%$ out of all nonneoplastic lesions respectively.

Out of 50 orchidectomy specimens 11 were neoplastic lesions, which constitute $22 \%$. Most of the neoplastic lesions were found in age of 2 nd and 3rd decades, comprised total 8 out of 11 cases. Out of the total 11 neoplastic lesions in this study, $73 \%$ means 8 cases comprised of germ cell tumors, which was $78.57 \%$ \& $62.5 \%$ in the study done by Hemavathi Reddy et al ${ }^{[3]}$ and Karki at al [2] respectively. Among the 8 cases of germ cell tumors in this study, mixed germ cell tumors and seminoma comprised about $37.5 \%$ each which is similar to 30 $40 \%$ in study by Karki et $\mathrm{al}^{[2]}$.

Sertoli cell tumour comprises about 27\% (3 cases) of total neoplastic lesions. Yolk sac tumour and embryonal carcinoma comprise about $9 \%$ each in our study. Age group of patients studied among neoplastic lesions in 3rd decade was $45.4 \%$ in present study while in study done by Syed Q et al $(39.7 \%)$ and Deotra et al $(32 \%)^{[1]}$.

\section{Conclusion}

Our study concluded that non neoplastic lesions of testis are commoner than neoplastic lesions. The incidence of Non-neoplastic lesions of the testis are most common in the 4th decade while malignancy was common in 2nd to 3rd decade of life according to our study. Out of all non-neoplastic lesions, normal histology was the predominant finding followed by atrophic testis. Germ cell tumors formed the bulk of neoplastic lesions. Amongst them Seminomas \& Mixed germ cell tumours were the most common ones.

\section{References}

1. Deotra A, Mathur DR Vyas MC. An 18 years study of testicular tumour in Jodhpur, western Rajasthan. Ind. Journal of surgery 1994:40(2):68-70.

2. Karki S, Bhatta RR. Histopathological analysis of testicular tumors. Journal of Pathology of Nepal (2012) Vol. 2, 301-304

3. Hemavathi Reddy et al. Histomorphological analysis of testicular lesions. Indian Journal of Pathology and Oncology, OctoberDecember 2016;3(4);558-563

4. Mahesh B. Patel, H. M. Goswami, U. R. Parikh, N. Mehta. Histo-Pathological study of testicular lesions. Gujarat Medical Journal / March-2015 Vol. 70 No. 1

5. Robertson GS. Br J Surg. 1995. Mar, 82(3): 342-5.

6. Kressel K, SchnellDet al, Eur urol. 1988; 15 (3-4): 200-4.

7. Haas GP, Shumaker BP, Cerny JC. High incidence of benign testicular tumors, J Urol. 1986, Dec; 136(6): 1219-1220.

8. Srinivasan A, Cinman N, Feber K, Gitlin J, Palmer L. History and physical examination findings predictive of testicular torsion: An attempt to promote clinical diagnosis by 
house staff. Journal of Pediatric Urology. 2011;7(4):470-474. 13.

9. Rizvi SAA, Ahmad I, Siddiqui MA, Zaheer S, Ahmad K. Role of Color Doppler Ultrasonography in Evaluation of Scrotal Swellings. Urology Journal 2011; 8(1):60-5. 14. 